\title{
Negating the Inflation Potential of the Fed's Lending Programs
}

\author{
Daniel L. Thornton, Vice President and Economic Adviser
}

ก he Term Auction Facility (TAF), instituted in December 2007, was the first in a series of Fed lending facilities designed to allocate credit (and thus liquidity) to certain institutions and markets. The most recent of these lending facilities is the Term Asset-Backed Securities Loan Facility (TALF), which began operation in March 2009. Initially the Fed sterilized the effect these loans would have had on the monetary base by selling government securities. Beginning in mid-September 2008, though, the Fed allowed the effect of its lending activities to pass through to the monetary base. Since August 2008, the monetary base has more than doubled, to about $\$ 1.7$ trillion dollars. Moreover, given the Fed's intention to purchase additional long-term Treasuries and mortgage-backed securities, the base could expand much further. Many analysts have expressed concern about the potential inflationary consequences if the extraordinary increase in the monetary base were allowed to persist. This synopsis analyzes the desirability of two suggestions for reducing the inflationary consequences of the Fed's new lending facilities: paying interest on reserves and allowing the Fed to issue debt.

The Fed has wanted to pay interest on reserves for more than 30 years. Initially, the desire was to reduce the reserve tax associated with the Federal Reserve's imposed reserve requirements. More recently, analysts suggested that paying interest on reserves would provide the Fed with an additional monetary policy tool. ${ }^{1}$ Specifically, it was thought that the funds rate could be anchored at the Federal Open Market Committee (FOMC)'s target for the funds rate by paying the target rate on reserves. With the funds rate anchored by the interest rate paid on reserves, the FOMC would be free to use open market operations to pursue other objectives.

The Fed began paying interest on reserves on October 9, 2008. Rather than paying interest only on required reserves, however, the Fed pays interest on both required and excess reserves. Currently, the rate is the upper end of the FOMC's target for the federal funds rate, 25 basis points. Some analysts believe that because the Fed is paying interest on excess reserves, depository institutions will be content to hold excess reserves - rather than lend them and, thereby, increase the supply of money. (It is believed that an increase in the monetary base that is not accompanied by an increase in the money supply will not be inflationary.)

\section{The sale of typical securities would force the Fed to contract its lending programs, whereas the sale of Fed bills would not.}

Paying interest on reserves is not likely to effectively prevent inflation for at least two reasons. First, depository institutions have an incentive to lend out excess reserves whenever the risk-adjusted interest rate on loans exceeds the rate paid on excess reserves. Because lending rates are typically much higher than the FOMC's target for the federal funds rate, at some point depository institutions will have an incentive to make loans rather than hold excess reserves. The Fed would have to pay a relatively high rate of interest on excess reserves to prevent this scenario. Given the extraordinary level of excess reserves, the cost to the Fed would be very high. Of course, the Fed would pay the interest by simply increasing the depository institution's account at the Fed, causing excess reserves to increase further.

A second problem arises because depository institutions sweep their deposits to reduce their effective reserve requirements from their statutory level. ${ }^{2}$ The effective average reserve requirement on transactions deposits is significantly lower than the 10 percent statutory requirement. With excess reserves currently at about $\$ 790$ billion (compared with about $\$ 2$ billion in August 2008), depository institutions could increase the M1 money supply measure dramatically with a relatively small decline in excess reserves. For example, if the effective reserve requirement is 5 percent, transactions deposits could increase by more than $\$ 400$ billion 
(about a 25 percent increase from its current level) with just a $\$ 20$ billion reduction in excess reserves. Consequently, excess reserves could remain "large" and the money supply could expand significantly.

The second suggestion for controlling the inflationary consequences of the recent monetary base growth is to allow the Fed to issue debt, sometimes called Fed bills. This would require congressional action because the Fed is not authorized to do this under the current provisions of the Federal Reserve Act.

The sale of Fed bills would reduce the monetary base in exactly the same way as a Fed sale of government or other securities that it holds. The difference, of course, would be that the sale of typical securities would force the Fed to contract its lending programs, whereas the sale of Fed bills would not. This authority would enable the Fed to not only reduce the monetary base without reducing the credit it has extended during the current financial market turmoil, but also make loans to specific institutions or markets at any time in the future without increasing the monetary base. Given the authority to issue its own debt, the Fed would be able to reallocate credit in the market for whatever purpose it deems necessary or desirable without affecting the funds rate, the monetary base, or the growth of monetary aggregates.

Issuance of Fed bills is a reallocation of credit because the Fed would be borrowing from one segment of the market (i.e., from whomever purchases Fed bills) and relending those funds to another. ${ }^{3}$ Apart from the issue of the efficacy of such credit reallocation practices, this new authority might compromise the Fed's independence. Specifically, the Fed might be pressured to extend credit to a particular institution, group of institutions, or market. The issue of Fed independence here differs from the historical issue of Fed independence, which centered on the extent to which the Fed would be required to finance government deficits by increasing the money supply. This issue of independence is different because the Fed would be able to reallocate credit without financing government spending per se. Nevertheless, by borrowing in the market and relending to specific institutions or markets, the Fed would be given a role that has heretofore been the purview of Congress. The borrowing and relending activities of the Fed would not be fundamentally different from the activities of Freddie Mac and Fanny Mae, two government-sponsored agencies that issued debt and lent the proceeds in the real estate market. If the Fed were to become less independent from Congress in this respect, it may become less independent in choosing the extent to which it should finance deficit spending. The evidence indicates that less-independent central banks tend to perform more poorly in keeping inflation low and stable. ${ }^{4}$

\footnotetext{
${ }^{1}$ For example, see Goodfriend, Marvin. "Interest on Reserves and Monetary Policy." Federal Reserve Bank of New York Economic Policy Review, May 2002, 8(1), pp. 13-29.

2 See Anderson, Richard G. and Rasche, Robert H. "Retail Sweep Programs and Bank Reserves, 1994-1999." Federal Reserve Bank of St. Louis Review, January/ February 2001, 83(1), pp. 51-72.

${ }^{3}$ See Thornton, Daniel L. "The Fed, Liquidity, and Credit Allocation." Federal Reserve Bank of St. Louis Review, January/February 2009, 91(1), pp. 13-22.

${ }^{4}$ For example, see Alesina, Alberto and Summers, Lawrence H. "Central Bank Independence and Macroeconomic Performance: Some Comparative Evidence." Journal of Money, Credit, and Banking, May 1993, 25(2), pp. 151-62.
} 